\title{
PROGRESIVISME JOHN DEWEY DAN PENDIDIKAN PARTISIPATIF PERSPEKTIF PENDIDIKAN ISLAM
}

\author{
Ilun Mualifah \\ (Dosen PAI Fak. Tarbiyah IAIN Sunan Ampel)
}

\begin{abstract}
Abstrak
Artikel ini berisi tentang konsep pendidikan partisipatif yang dikaitkan dengan konsep progresivisme pendidikan John Dewey, dan kemudian dikaji dalam perspektif pendidikan Islam. Konsep pendidikan partisipatif dalam progresivisme pendidikan John Dewey merupakan konsep pendidikan yang mengacu pada teori-teori John Dewey yang berpijak pada asas-asas progresivitas. Asas progresivitas berprinsip pada sikap optimistis dalam memandang kemajuan peserta didik dalam proses pendidikannya. Konsep progresivisme pendidikan John Dewey yang megandung asas pendidikan partisipatif dalam pandangan pendidikan Islam bisa dipertegas: bahwa terdapat beberapa aspek kesesuaian (terutama dalam hal kemanfaatan yang bersifat duniawi), dan terdapat banyak aspek perbedaan yang sangat prinsip (terutama mengenai hal-hal yang bersifat metafisik-spiritual). Dengan demikian, ketika akan menerapkan asas partisipatif dalam konsep pendidikan Dewey di dalam kehidupan umat Islam, perlu difilter terlebih dahulu dengan kacamata nilai-nilai Islam. Apabila tidak bertentangan dengan nilai-nilai Islam, maka perlu diterapkan; namun apabila bertentangan dengan nilai-nilai Islam, maka tidak perlu diterapkan (cukup dijadikan pengetahuan saja).
\end{abstract}

Kata Kunci: Pendidikan Partisipatif, Progresivisme John Dewey, Pendidikan Islam 


\section{A. Pendahuluan}

Pendidikan bertanggung jawab dalam membina peserta didik agar dewasa, berani mandiri dan berusaha sendiri. Dengan demikian, nuansa pendidikan semestinya diupayakan agar memberikan kesempatan kepada peserta didik untuk selalu berfikir secara mandiri dan kritis (independent critical thinking) dalam rangka menemukan jati dirinya. Dalam konteks ini, yang terpenting bukanlah memberikan pengetahuan positif yang bersifat taken for granted kepada peserta didik, tetapi bagaimana mengajarkan kepada peserta didik agar memiliki kekuatan bernalar (the power reasoning). Salah satu upaya untuk menuju ke sana adalah dengan pendekatan proses pendidikan yang bersifat partisipatif (pendidikan partisipatif); suatu model pendidikan yang memberikan porsi besar kepada peserta didik dalam mengembangkan keilmuan dan cara berfikirnya. Di sini, diasumsikan bahwa pendidikan partisipatif banyak tertuang dalam konsep progresivisme pendidikan.

Progresivisme merupakan suatu faham yang berdasar pada sebuah asumsi bahwa manusia itu mempunyai kemampuan yang wajar dan dapat mengatasi berbagai permasalahan yang mengancam manusia itu sendiri. Sejalan dengan itu progresivisme ${ }^{1}$ menolak corak pendidikan yang otoriter yang terjadi di masa lalu dan sekarang. Pendidikan yang otoriter diasumsikan bisa menghambat diri dalam mencapai tujuan-tujuan yang baik, karena kurang menghargai kemampuan yang dimiliki manusia dalam proses pendidikan. Padahal dalam pendidikan semuanya ibarat motor penggerak sebagai proses untuk mencapai kemajuan atau "progres". Dengan demikian, bagi progresivisme, ide-ide, teori-teori, dan/atau cita-cita tidaklah cukup hanya diakui sebagai hal-hal yang ada (being), tetapi yang ada ini harus dicari artinya bagi suatu kemajuan atau maksud-maksud baik yang lain.

Bagi progresivisme, pengetahuan yang diajarkan bersumber dari pengalaman yang terkendali, seperti, IPA dan teknologi, sehingga harus disampaikan secara mantap. Pengetahuan ini dihimpun atas dasar pengamatan yang teratur. Ketika para observer menjumpai gejala atau data, maka ia bertanya dan berusaha menguji apakah data itu benar-benar

\footnotetext{
${ }^{1}$ Imam Barnadib, Filsafat Pendidikan: Sistem \& Metode, cet. 9 (Yogyakarta: ANDI, 1997), 59
} 
yang dicari. Pengujian itu didasarkan pada kritreria yang telah ditetapkan, dan sampailah ia pada kesimpulan apakah sesuai ataukah tidak pengetahuan tersebut. Pengetahuan ini bersumber dari pengalaman yang terkendali. $^{2}$

\section{B. Sekilas tentang John Dewey}

John Dewey (selanjutnya disebut Dewey), lahir di Burlington, Vermount (Amerika) pada tanggal 20 Oktober 1859, dan menetap di sana sampai lulus sekolah menengah. ${ }^{3}$ Setelah itu ia masuk di Universitas Vermount tahun 1875. Tahun 1879 Dewey menerima "diploma kandidat", kemudian ia mengajar di sebuah sekolah selama 3 tahun. Pasca itu, ia masuk ke perguruan tinggi John Hopkins untuk mempelajari filsafat dan psikologi. Ia pernah juga menjadi asisten dosen lalu diangkat menjadi dosen filsafat di Minnosota. ${ }^{4}$ Dua tahun kemudian (1884), ia menyelesaikan studI filsafat dengan gelar Ph.D dari The John Hopkins University dengan disertasi The Psychology of Kant. ${ }^{5}$

Pada tahun 1884 Dewey menulis buku bersama J.A.Mc Iellan dengan judul Applied Psychology: An Introduction to the Principles and Practice of Education. ${ }^{6}$ Ia juga mengajar di Universitas Michigan dan Minnosota, ${ }^{7}$ dan memberikan kuliah filsafat di beberapa lembaga. Di samping filsafat, perhatian Dewey juga tertuju pada bidang pendidikan. Pada tahun 1890 Dewey pindah ke Chicago dan menjabat sebagai Kepala Bagian Filsafat, Pendidikan, dan Psikologi. ${ }^{8}$ Di usianya yang masih terbilang muda Dewey telah menjadi mahaguru dalam ilmu filsafat dan

\footnotetext{
${ }^{2}$ Imam Barnadib, Filsafat Pendidikan: Sistem \& Metode, 7

3 Djalaludin \& Abdullah Idi, Filsafat Pendidikan (Jakarta: Gaya Media Pratama, 1997), 70

${ }^{4}$ Y.B. Suparlan, Aliran-Aliran Baru dalam Pendidikan (Yogyakarta: Andi Offset, 1984), 82-84

5 Endang Daruni Asdi \& A. Husnan Aksara, Filsif-Filsuf Dunia dalam Gambar (Yogyakarta: Karya Kencana, 1982), 67

6 Wasty Soemanto \& Hendyat Soetopo, Dasar \& Teori Pendidikan Dunia: Tantangan bagi Para Pemimpin Pendidikan (Surabaya: Usaha Nasional, 1982), $118-120$

${ }^{7}$ Hamdani Ali, Filsafat Pendidikan (Yogyakarta: Kota Kembang, 1993), 149

${ }^{8}$ Y.B. Suparlan, Aliran-Aliran Baru dalam Pendidikan.
} 
pedagogik pada universitas di Chicago (1895) dan New York (1904). ${ }^{9}$ Pada tahun 1896 Dewey mendirikan sekolah eksperimental bidang ilmu jiwa dan pendidikan, dengan nama University Elementaire-School. ${ }^{10}$

Dewey tidak hanya populer di kalangan ahli filsafat profesional karena filsafatnya; tetapi juga di kalangan beberapa ahli, karena perkembangan idenya yang fundamental dalam bidang ekonomi, hukum, antropologi, teori politik, dan ilmu jiwa. Ia adalah juru bicara mengenai cara-cara kehidupan demokratis yang sangat populer di Amerika Serikat. ${ }^{11}$ Tokoh ini termasuk kelompok ekstrim dibanding tokoh lainnya. Selain itu, sumbangan Dewey dipandang sebagai kekuatan intelektual yang dapat menggerakkan perkembangan progresivisme.

Dewey dapat memberikan penghargaan dan menunjukkan pentingnya peranan berbagai teori dan praktik yang berasal dari beberapa tokoh pendidikan. Pada tahun 1905 ia pindah ke Columbia University di New York dan memberikan kuliah filsafat dan pendidikan di Teachers College. Ia tinggal di New York lebih dari 40 tahun, hingga pensiun mengajar di tahun 1930. Dewey meninggal pada tanggal 1 Januari (ada yang mengatakan Juni) tahun 1952 di New York. Beberapa karya Dewey: My Pedagogic Creed (1897); School and Society (1899); How We Think (1910); Democracy and Education (1916); Eksperience and Education (1938); dan Education Today (1940). ${ }^{12}$

Dalam My Pedagogic Creed Dewey menyatakan bahwa pendidikan itu adalah kehidupan dan bukan hanya persiapan untuk hidup; dalam School and Society ia menekankan bahwa sekolah harus terkait dengan konteks masyarakat; dalam How We Think ia mengajarkan bagaimana berfikir progresif; dalam Democracy and Education ia menanamkan model pendidikan yang demokratis; dalam Eksperience and Education ia menandaskan bahwa pendidikan harus mengacu kepada pengalaman; dan dalam Education Today Dewey mengajarkan bahwa pendidikan harus berpijak pada hari ini menuju hari depan.

\footnotetext{
${ }^{9}$ I. Djumhur \& H. Danasuparta, Sejarah Pendidikan (Bandung: CV. Ilmu, 1974), 89

${ }^{10}$ Wasty Soemanto \& Hendyat Soetopo, Dasar \& Teori Pendidikan Dunia.

${ }^{11}$ Hamdani Ali, Filsafat Pendidikan, 148,149

${ }^{12}$ Muis Sad Iman, Pendidikan Partisipatif (Yogyakarta: Safiria Insani Press \& MSI UII, 2004), 61
} 


\section{Mengenal Lebih Lanjut Progresivisme}

Progresivisme adalah suatu gerakan dalam bidang pendidikan yang -antara lain- dipelopori oleh John Dewey. Sejak awal kelahirannya aliran ini berusaha menggapai secara positif pengaruh-pengaruh yang ada pada iptek. Selain itu perubahan yang terjadi di masyarakat dipandang secara optimis dan dikembalikan kepada kemampuan manusia. Manusia sepanjang sejarahnya telah menciptakan kebudayaan dan peradaban sebagai hasil dari majunya iptek. Semua itu dipandang sebagai sesuatu yang progres sehingga aliran ini dikenal dengan progresivisme.

Bagi progresivisme, segala sesuatu itu dipandang ke depan. Semua yang ada di belakang hanya merupakan catatan-catatan yang berguna untuk dipelajari dan saat dibutuhkan dapat ditampilkan kembali pada zaman sekarang. Dengan demikian manusia dipandang sebagai makhluk yang dinamis dan kreatif. Oleh karena itu, pada dasarnya manusia adalah makhluk yang memiliki kebebasan, semua itu penting demi kemajuan yang diperlukan oleh manusia itu sendiri. ${ }^{13}$

Progresivisme melihat bahwa berfikir dengan kecerdasan adalah pegangan utama dalam pendidikan, ini hal yang signifikan. Hal ini akan menjadi lebih signifikan bila difahami dalam konteks kecerdasan yang lebih luas, seperti multiple intelligences yang telah dikenal dewasa ini; berarti yang dikembangkan bukan hanya kecerdasan yang bersifat linier matematis. ${ }^{14}$ Dalam kaitan ini progresivisme memandang bahwa peserta didik hendaknya tidak hanya dipandang sebagai individu, melainkan sebagai manusia yang berada di dalam jaringan lingkungan dan pengalaman. Hal ini berarti eksistensi kecerdasan tidak akan memadai bila terisolir.

Progresivisme juga melihat bahwa lingkungan yang ada, baik mengenai manusia maupun yang lain, tidak bersifat sama atau statis, tetapi selalu megalami perubahan. Perubahan tersebut disebabkan oleh kemampuan manusia yang mempelajari banyak hal dengan mengantisipasi hal-hal yang mungkin terjadi di masa mendatang. Meskipun yang dialami manusia itu kadang kekecewaan, tetapi itu akan diolah secara positif untuk keberhasilan di masa mendatang. Buktinya,

${ }^{13}$ Imam Barnadib, Filsafat Pendidikan: Sistem \& Metode, 24-25

${ }^{14}$ Imam Barnadib, Filsafat Pendidikan: Sistem \& Metode, 29 
berbagai kemajuan iptek telah berhasil mengungkap rahasia alam semesta yang bisa dimanfaatkan manusia sendiri.

Dalam pandangan Progresivisme, dengan adanya kemampuan manusia, maka segala yang ada diharapkan tidak berdampak negatif. Progresivisme juga memandang bahwa peserta didik mempunyai kemampuan bereksperimen dalam perjalanan hidupnya karena adanya bekal-bekal pengetahuan dan keterampilan yang telah dipelajari dan dimiliki. Yang dimaksud dengan bereksperimen adalah mampu mencari dan menemukan permasalahan serta alternatif-alternatif pemecahannya. ${ }^{15}$

\section{Pandangan Progresivisme tentang Realita Alam semesta}

Progresivisme tidak menggunakan istilah alam semesta, melainkan dunia. Dunia merupakan media proses dimana manusia hidup di dalamnya. Istilah dunia termasuk sinonim dengan kosmos, realita, dan alam. ${ }^{16}$ Dengan demikian bisa dikatakan bahwa ontologi progresivisme mengandung makna dan kualitas evolusionistis yang kuat. Untuk itu, pengalaman diartikan sebagai ciri dari dinamika hidup, dan hidup adalah perjuangan, tindakan, dan kemanfaatan; berarti pengalaman adalah perjuangan pula. Mengenai pengisian pengalaman, manusia mempunyai peranan lebih besar dibanding makhluk lain. Manusia bisa membuat simbol-simbol dan makna pengalamannya serta bisa menggambarkan masa depannya. Manusia mempunyai jiwa sebagai sumber dan pendorong yang penting untuk berbuat; yang ada adalah yang berbuat.

\section{Pandangan Progresivisme mengenai Pengetahuan}

Progresivisme membedakan antara pengetahuan dan kebenaran. Pengetahuan merupakan kumpulan kesan-kesan dan peneranganpenerangan yang terhimpun dari pengalaman-pengalaman yang siap untuk digunakan. Sementara kebenaran adalah hasil tertentu dari usaha untuk mengetahui, memiliki dan mengarahkan beberapa segmen pengetahuan agar dapat menimbulkan petunjuk atau penyelesaian pada situasi tertentu, yang mungkin keadaannya kacau. Dalam kaitan ini,

\footnotetext{
${ }^{15}$ Imam Barnadib, Filsafat Pendidikan (Yogyakarta: Adicita Karya Nusa, 2002), 5859

${ }^{16}$ Imam Barnadib, Filsafat Pendidikan: Sistem \& Metode, 29-30

Jurnal Pendidikan Agama Islam

Volume 01 Nomor 01 Mei 2013

Hal $106-121$
} 
kecerdasan merupakan faktor utama yang mempunyai kedudukan sentral, yang dapat mempertahankan adanya hubungan antara manusia dan lingkungan. ${ }^{17}$

\section{Pandangan Progresivisme mengenai Nilai}

Progresivisme tidak mengadakan pembedaan tegas antara nilai intrinsik dan nilai instrumental. Dua jenis nilai ini saling bergantung satu sama lain seperti halnya antara pengetahuan dan kebenaran. ${ }^{18}$ Misalnya, kesehatan itu bernilai baik, tidaklah semata-mata suatu ilustrasi tentang nilai intrinsik, tetapi itu akan dihubungkan dengan segi-segi operasional; bahwa kesehatan yang baik akan mendatangkan kesejahteraan bagi masyarakat.

\section{Pandangan Progresivisme tentang Belajar}

Pandangan progresivisme mengenai belajar bertumpu pada pandangan mengenai peserta didik sebagai makhluk yang mempunyai kelebihan dibandingkan dengan makhluk-makhluk lain. Di samping itu, menipisnya dinding pemisah antara sekolah dan masyarakat menjadi pijakan pengembangan ide-ide pendidikan progresivisme. Peserta didik mempunyai akal dan kecerdasan sebagai potensi yang merupakan kelebihan dibandingkan dengan makhluk lain. Dengan kecerdasan serta sifatnya yang dinamis dan kreatif, peserta didik mempunyai bekal untuk menghadapi dan memecahkan problem-problem yang ada. Terkait dengan itu, usaha untuk meningkatkan kecerdasan adalah tugas utama dalam pendidikan.

Peserta didik hendaklah dipandang tidak sekedar sebagai makhluk yang berkesatuan jasmani dan ruhani saja, melainkan juga manifestasinya sebagai tingkah laku dan perbuatan yang berada dalam pengalamannya. Jasmani dan ruhani -terutama kecerdasan- perlu difungsikan secara aktif dalam memanfaatkan lingkungannya secara optimal. Ia perlu mendapat kebebasan dalam mengambil bagian dalam kejadian-kejadian yang berlangsung di sekitarnya. Di sini, agar sekolah

${ }^{17}$ Imam Barnadib, Filsafat Pendidikan: Sistem \& Metode, 31

${ }^{18}$ Imam Barnadib, Filsafat Pendidikan: Sistem \& Metode, 32 
dapat berlaku wajar, maka perlu terbuka dan tidak perlu ada dinding pemisah dengan masyarakat. Sekolah merupakan miniatur masyarakat kecil.

Dengan demikian diharapkan bahwa peserta didik dapat menghayati belajar yang edukatif, dan bukan mis-edukatif. Yang pertama adalah belajar, yang secara bijaksana ditujukan untuk mencapai hasilhasil yang konstruktif, yang nilai-nilai dan syarat-syaratnya ditentukan berdasarkan konsepsi yang baik, yang dikehendaki oleh kebudayaan negara atau bangsa. Sementara yang kedua, belajar mis-edukatif, ialah yang ditentukan oleh nilai-nilai yang kurang mendorong ke arah perkembangan yang dinamis, yang mengandung unsur-unsur yang berlawanan. Belajar model kedua bersifat tidak serasi dengan tujuan. Untuk suasana belajar edukatif, bisa dilaksanakan di dalam kelas maupun di luar kelas, sehingga pendidikan merupakan hidup itu sendiri. ${ }^{19}$

\section{Pandangan Progresivisme mengenai Kurikulum}

Progresivisme -yang berpijak pada asas fleksibilitas, dinamika, dan sifat-sifat lain yang sejenis, tercermin dalam pandangannya mengenai kurikulum sebagai pengalaman yang edukatif, bersifat eksperimental dan adanya rencana serta suasana yang teratur. Pengalaman yang edukatif maksudnya pengalaman apa saja yang mengandalkan keserasian antara elemen-elemen pendidikan dengan tujuan yang ingin dicapai. Oleh karena tidak ada standar yang universal, maka kurikulum yang ada harus terbuka terhadap pembenahan dan penyempurnaan. Fleksibilitas ini didasarkan pada kebutuhan peserta didik, dan juga disesuaikan dengan kondisi setempat.

Oleh karena sifat kurikulum yang tidak beku, maka jenis yang memadai adalah kurikulum yang berpusat pada pengalaman. Jenis ini, digambarkan oleh Theodore Brameld $^{20}$ sebagai kurikulum yang melepaskan diri dari semua sekat mata pelajaran dan menekankan pada unit-unit, yang dibentuk dan dihasilkan dari pengalaman peserta didik sendiri yang diarahkan kepada pengembangan kepribadiannya secara

\footnotetext{
${ }^{19}$ Imam Barnadib, Filsafat Pendidikan: Sistem \& Metode, 35-36

20 Theodore Brameld, Philosophies of Education in Cultural Perspective (New York: The Dryden Press, 1958), 173
}

Jurnal Pendidikan Agama Islam

Volume 01 Nomor 01 Mei 2013

Hal $108-121$ 
penuh dengan jalan penghayatan-penghayatan emosional, motor, intelektual, dan sosial yang seluas dan sekaya mungkin.

Selain itu, yang dipandang maju oleh progresivisme adalah kurikulum jenis "Core Curriculum", yakni sejumlah pengalaman belajar di sekitar kebutuhan umum. ${ }^{21}$ Kurikulum-kurikulum tersebut harus disusun secara teratur dan terencana. Kualifikasi semacam ini diperlukan agar pendidikan dapat mempunyai proses sesuai dengan tujuan, tidak mudah terpengaruh oleh hal-hal yang sifatnya insidental dan tidak penting. Dengan demikian jelaslah bahwa suasana pendidikan yang baik adalah yang dapat diarahkan sesuai dengan arah yag ditentukan dalam pendidikan

\section{Progresivisme John Dewey}

John Dewey dalam Creative Intellegence menyatakan bahwa sifat utama dari pragmatisme tentang realita, sebenarnya bisa dikatakan bahwa tiada teori mengenai realita yang umum. ${ }^{22}$ Di antara kaum pragmatis (selanjutnya menjadi progresivis) Dewey mempunyai pandangan yang ekstrim, sebab tokoh-tokoh lain seperti George Santayana, John Childs tidak demikian. Mereka menyatakan bahwa metafisika itu ada, karena pragmatisme mempunyai konsep tentang eksistensi. Misal, dari segi eksistensi, alam bukan dipandang sebagai sesuatu yang substansial, melainkan dipandang dari segi prosesnya. ${ }^{23}$

John Dewey memandang bahwa sekolah merupakan lingkungan masyarakat kecil, dan cerminan daripadanya. Ini merupakan bentuk kehati-hatian dalam pengelolaan sekolah terhadap masyarakat. Setidaknya, sekolah jangan hanya sebagai "menara gading" yang menjulang jauh di atas masyarakat. Keduanya perlu saling berinteraksi secara positif. Pandangan ini perlu dipegang dengan teguh disertai harapan terwujud, meskipun realisasinya tidak semata hasil terjemahan harfiah. ${ }^{24}$ Progresivisme merupakan intervensi atau tejemahan dalam hal

\footnotetext{
${ }^{21}$ Imam Barnadib, Filsafat Pendidikan: Sistem \& Metode, 37

${ }^{22}$ J. Donald Butler, Four Philosophies and Their Practice in Education and Religion (New York: Harper and Brothers, 1951), 429-450.

${ }^{23}$ Imam Barnadib, Filsafat Pendidikan: Sistem \& Metode, 29

${ }^{24}$ Imam Barnadib, Filsafat Pendidikan, 61-62
} 
pendidikan yang dihubungkan dengan orientasi tahap awal munculnya masyarakat berteknologi di Amerika. ${ }^{25}$

Mengenai pendidikan progresiv, Dewey menulis bahwa pendidikan itu mengehendaki (dalam tingkatan yang urgen) adanya filsafat pendidikan yang berlandaskan pada filsafat pengalaman. Secara singkat Dewey menyinggung adanya kesatuan rangkaian pengalaman. Kesatuan rangkaian pengalaman ini mempunyai dua aspek penting bagi pendidikan; 1) Hubungan kelanjutan di antara individu dan masyarakat, dan 2) Hubungan kelanjutan di antara fikiran dan benda. Dewey sejalan dengan Plato, bahwa tidak ada individu atau masyarakat yang lepas antara satu dengan yang lain. Fikiran pun tidak bisa lepas dari aktivitas mental dan pengalaman. ${ }^{26}$

Sudah jelas bahwa betapa pentingnya arti bekerja itu. Bekerja memberikan pengalaman, dan pengalaman memimpin orang untuk berfikir, sehingga orang dapat bertindak bijaksana dan benar. Pengalaman mempengaruhi pula budi pekerti orang. Ada pengalaman positif dan ada pengalaman negatif. Pengalaman positif merupakan pengalaman yang benar, pengalaman yang berguna dan dapat diterapkan dalam kehidupan. Sementara pengalaman negatif adalah pengalaman yang tidak benar, merugikan, atau menghambat kehidupan dan tidak perlu dipakai lagi. ${ }^{27}$ Pengalaman dalam suatu waktu terdiri dari beberapa aspek yang saling berhubungan dan sebagai rentetan kejadian. ${ }^{28}$ Sebuah pengalaman harus bisa dibuktikan berguna atau tidak; yang tidak berguna harus dibuang. ${ }^{29}$

Dalam memandang norma kesusilaan, Dewey berdasar pada pandangan bahwa suatu perbuatan dinilai luhur, jika itu memberikan hasil yang baik bagi pergaulan hidup. Dalam pada itu antara kehidupan individu dan masyarakat, yang lebih diutamakan adalah kepentingan masyarakat (pendidikan sosialistis), sebab kehidupan individu tidak ada gunanya tanpa adanya masyarakat. Dewey tidak mengehendaki adanya kaidah yang permanen, tetapi kaidah itu berubah dari waktu ke waktu

\footnotetext{
${ }^{25}$ Imam Barnadib, Filsafat Pendidikan, 80

${ }^{26}$ Muis Sad Iman, Pendidikan Partisipatif, 47

27 Ag. Soejono, Aliran Baru dalam Pendidikan, bagian 1 (Bandung: CV. Ilmu, 1978), 128-130

${ }^{28}$ Muis Sad Iman, Pendidikan Partisipatif. 69

${ }^{29}$ Hamdani Ali, Filsafat Pendidikan, 151-153
} 
disesuaikan dengan kondisi zaman. Tidak ada sesuatu yang tetap, kaidah harus ditinjau lugas, obyektif, teliti, jujur seperti dalam laboratorium. The truth is in the making. ${ }^{30}$

Menurut Dewey, pendidikan itu memberikan kesempatan hidup. Hidup itu menyesuaikan diri dengan masyarakat. Kesempatan diberikan dengan jalan berbuat secara individual maupun kelompok untuk mendapatkan pengalaman sebagai suatu modal berharga dalam berfikir kritis secara produktif dan berbuat susila. Sekolah yang dikehendaki Dewey adalah "sekolah kerja". Masyarakat harus menyediakan segala sesuatu yang dibutuhkan warganya untuk pendidikannya, agar tidak bergantung pada dogma, melainkan berfikir secara bebas, disiplin, obyektif, kreatif, dan dinamis. ${ }^{31}$ Bagi Dewey peserta didik memiliki empat (4) insting; yakni insting sosial, membentuk/membangun, menyelidiki, dan kesenian.

Bagi Dewey, pendidikan memang merupakan kebutuhan hidup. Pendidikan merupakan suatu transmisi yang dilakukan melalui komunikasi. Komunikasi adalah proses dari pernyataan empiris dan proses modifikasi watak, sehingga menjadi suatu keadaan pribadi. Hal ini dapat dikatakan bahwa setiap rancangan sosial memiliki bagian penting dari sebuah kelompok, dari yang tertua hingga yang termuda. Sebagai sebuah masyarakat yang sangat kompleks dalam struktur maupun sumber daya, membutuhkan pengajaran formal serta proses pembelajaran. ${ }^{32}$

Dewey menegaskan bahwa pendidikan itu "preparing or getting ready for some future duty or privilege" (mempersiapkan atau mendapat kesiapan untuk banyak tugas atau tanggung jawab di masa mendatang). Lebih lanjut, menurut Dewey, "the notion that education is an unfolding from within appears to have more likeness to the conception of growth which has been set forth. ${ }^{33}$ Dengan demikian pemikiran Dewey tentang pendidikan lebih condong kepada suatu konsepsi pendidikan yang harus

\footnotetext{
${ }^{30}$ Muis Sad Iman, Pendidikan Partisipatif.

${ }^{31}$ Muis Sad Iman, Pendidikan Partisipatif, 71

32 John Dewey, Democracy and Education, an Introduction to the Philosophy of Education, Twenty-Third Printing (USA: The Macmillan Company, 1950), 11

${ }^{33}$ John Dewey, Democracy and Education, 79
} 
dibentangkan dari yang tampak dan memiliki banyak kesamaan konsepsi pertumbuhan yang menjadi perlengkapan seterusnya. ${ }^{34}$

Inilah antara lain pandangan progresivisme pendidikan John Dewey yang mengehendaki adanya asas fleksibilitas demi memajukan pendidikan. Untuk tujuan itu, menurut Dewey, pendidikan harus bersifat demokratis; dan untuk mencapai demokratisasi pendidikan diperlukan modal yang besar, sehingga -bisa dikatakan- bahwa Dewey sangat mendukung terhadap program-program kapitalisme. "We still find a view put forth as to an intrinsic and necessary connection between democracy and capitalism which has a psychological foundation and temper. For it is only because of belief in ascertain theory of human nature that the two are said to be siamese twins, so that attack upon one is threat directed at the life of the other", kata Dewey. ${ }^{35}$

\section{E. Pendidikan Partisipatif dalam Progresivisme John Dewey}

Pendidikan partisipatif dapat diartikan sebagai proses pendidikan yang melibatkan semua komponen pendidikan, khususnya peserta didik. ${ }^{36}$ Dalam bahasa Imam Barnadib ${ }^{37}$, pendidikan partisipatif adalah salah satu konsep pendidikan yang -langsung maupun tidak- muncul karena adanya perkembangan labih lanjut dari progresivisme. Pendidikan partisipatif biasanya dimaknai dengan pendidikan yang dalam prosesnya melibatkan partisipasi aktif dari berbagai fihak; baik pemerintah, pendidik, peserta didik, orang tua peserta didik, masyarakat, dan elemen-elemen lain. Semua terlibat aktif dalam proses pendidikan untuk mencapai satu titik yang sama, yaitu mencerdaskan kehidupan bangsa. Meski demikian, yang disampaikan di atas, bukanlah tafsiran tunggal terhadap makna pendidikan partisipatif.

Dalam konteks inilah pendidikan lebih berfungsi untuk memberikan kebebasan dan kemerdekaan kepada peserta didik, sehingga potensi-potensi yang dimiliki peserta didik bisa berkembang dengan baik. Berangkat dari sini, para pendidik hendaknya memandang peserta didik

\footnotetext{
${ }^{34}$ Muis Sad Iman, Pendidikan Partisipatif, 86

${ }^{35}$ John Dewey, Freedom and Culture (Capricorn Books Edition, 1963), 105

${ }^{36}$ Muis Sad Iman, Pendidikan Partisipatif, 4

${ }^{37}$ Muis Sad Iman, Pendidikan Partisipatif, xi-xii 
sebagai komunitas yang selalu khas dan unik, sehingga pendidik dituntut agar mampu mengeksplorasi kemampuan, kecerdasan, kecenderungan, minat dan bakat peserta didik yang sangat beragam. Oleh karenanya, salah satu ukuran penting untuk menilai keberhasilan pendidikan adalah sejauhmana proses pendidikan itu mampu mengeksplorasi kecerdasan, minat dan bakat peserta didik, serta mengembangkannya secara baik dan maksimal.

Senada dengan semangat pendidikan partisipatif, Malcolm Knowles dalam publikasinya yang berjudul The Audult Learner, A Neglected Species, menawarkan teori belajar yang tepat bagi orang dewasa, yang disebut dengan istilah "Andragogi". 38 Teori ini mengungkapkan bagaimana proses pendidikan harus dilaksanakan dengan melibatkan partisipasi aktif dari peserta didik. Konsep andragogi ini merupakan pengembangan dari konsep pedagogi yang selama ini dianut dalam prkatik pendidikan pada umumnya.

Istilah "Andragogi" berasal dari bahasa Yunani kuno; yakni "Andr" yang berarti laki-laki atau orang dewasa -bukan anak laki-laki, dan "Ogogos" yang berarti membimbing atau membina. Secara harfiah (etimologi), andragogi berarti ilmu atau seni mengajar orang dewasa. Sementara itu istilah "Pedagogi" berasal dari bahasa Yunani kuno; yakni "Paid" yang berarti anak, dan "Ogogos" yang berarti membina atau membimbing. Jadi secara harfiah pedagogi berarti seni mengajar atau mendidik anak-anak. Yang sering dilaksanakan selama ini adalah praktik yang kedua; sehingga tidak mengeherankan jika praktik pendidikan selama ini lebih berupa indroktinasi, dan kurang menekankan pada keterlibatan peserta didik dalam proses pendidikan.

Dalam mengembangkan konsep andragogi, Malcolm ${ }^{39}$ mengemukakan empat asumsi pokok. Pertama, konsep diri. Asumsinya ialah bahwa kesungguhan dan kematangan diri seseorang itu bergerak dari ketergantungan total (realita pada bayi) menuju ke arah pengembangan diri sehingga mampu mengarahkan dirinya sendiri dan mandiri. Dengan kata lain, secara umum konsep diri anak-anak itu masih tergantung sedangkan pada orang dewasa konsep dirinya sudah mandiri.

${ }^{38}$ Muis Sad Iman, Pendidikan Partisipatif, 4-5

${ }^{39}$ Murtadha Muthahari, Fitrah (Jakarta, 1419/1998), 6-17. 
Oleh karena kemandirian inilah orang dewasa membutuhkan penghargaan orang lain sebagai manusia yang mampu menentukan dirinya sendiri (sel determination) dan mampu mengarahkan dirinya sendiri (self direction). Apabila orang dewasa tidak menemukan dan menghadapi situasi dan kondisi yang memungkinkan timbulnya penentuan diri sendiri dalam suatu pelatihan, maka akan menimbulkan penolakan atau reaksi yang kurang menyenangkan. Orang dewasa juga mempunyai kebutuhan psikologis yang mendalam agar secara umum menjadi mandiri, meski dalam situasi tertentu boleh jadi ada ketergantungan yang sifatnya sementara.

Kedua, peranan pengalaman. Asumsinya adalah bahwa sesuai dengan perjalanan waktu, seorang individu tumbuh dan berkembang menuju ke arah kematangan. Dalam perjalanannya, seorang individu mengalami dan mengumpulkan berbagai pengalaman yang dijalaninya dalam hidup, dimana hal ini menjadikan seorang individu sebagai sumber belajar yang demikian kaya, dan pada saat yang sama individu tersebut memberikan dasar yang luas untuk belajar dan memperoleh pengalaman baru. Konsep belajar dalam hal ini dikenal dengan Eksperiential Learning Cycle (proses belajar berdasarkan pengalaman).

Ketiga, kesiapan belajar. Asumsinya bahwa setiap individu semakin menjadi matang, maka kesiapan belajar bukan ditentukan oleh paksaan akademik dan biologisnya, tetapi lebih banyak ditentukan oleh tuntutan perkembangan dan perubahan tugas dan peran sosialnya. Pada seorang anak, belajar lebih karena adanya tuntutan akademik atau biologis; sedangkan pada orang dewasa kesiapan belajar lebih karena tingkatan perkembangan mereka yang harus menghadapi peranannya sebagai pekerja, orang tua, pemimpin, atau profesi yang lain.

Keempat, orientasi belajar. Asumsinya adalah bahwa pada anak orientasi belajarnya sudah ditentukan dan dikondisikan untuk memiliki orientasi yang berpusat pada materi pembelajaran (subject matter centered orientation). Sementara pada orang dewasa mempunyai kecenderungan orientasi belajar yang berpusat pada pemecahan permasalahan yang dihadapi (problem centered orientation). Hal ini karena belajar bagi orang dewasa merupakan kebutuhan untuk menghadapi permasalahan yang dihadapi dalam kehidupan keseharian, terutama kaitannya dengan fungsi dan peran sosial. 
Konsep belajar orang dewasa yang dibangun di atas empat asumsi tersebut, pada gilirannya dapat digunakan sebagai dasar pijak bagi pengembangan "pendidikan partisipatif". Sebagai salah satu konsep pendidikan, pendidikan partisipatif tentu tidak cukup hanya dibangun di atas empat asumsi di atas, tetapi dasar-dasar ontologis, epistemologis, dan epistemologis juga perlu dielaborasi. Dalam konteks inilah progresivisme pendidikan (terutama konsep Dewey) amat sejalan dengan konsep pendidikan partisipatif. Dalam progresivisme, proses pendidikan dilakukan dengan memberikan kebebasan yang besar kepada peserta didik untuk menemukan kebenaran pengetahuan dan enjoy dalam proses belajarnya.

Konsep pendidikan dalam progresivisme Dewey sejalan dengan konsep pertumbuhan manusia. Ia akan terus mengikuti perkembangan secara fleksibel sepanjang manusia itu masih tumbuh dan berkembang; maka pendidikan akan terus berjalan ke depan secara dinamis. Hal ini relevan dengan konsep live long education (pendidikan seumur hidup). Progresivisme Dewey juga amat menekankan konsepnya pada pendidikan yang berdasarkan pada pengalaman. Hal ini tentu dapat dikembangkan sebagai basis filosofis bagi pendidikan partisipatif. Peserta didik diberikan pendidikan sesuai dengan kadar pengalaman yang dimiliki, sehingga lebih memungkinkan untuk melibatkan dirinya secara aktif dalam setiap proses pendidikan. Ingat pada apa yang telah diteorikan Malcolm Knowles ketika menjelaskan konsep pendidikan bagi orang dewasa; salah satu asumsi yang dibangun adalah Eksperietial Learning Cycle (proses belajar berdasarkan pengalaman). ${ }^{40}$

Dengan demikian, progresivisme pendidikan John Dewey memuat konsep-konsep pendidikan partisipatif, dimana partisipasi semua fihak -terutama- peserta didik- sangat ditekankan dalam rangka kemajuan pendidikannya dan pendidikan manusia pada umumnya. Peran pendidik bukanlah sebagai seorang figur yang seakan sok tahu dan mahatahu. Pendidik hanya sebagai fasilitator bagi peserta didik, pembimbing, dan penuntunnya. Proses kontribusi keilmuan dalam pendidikan partisipatif (yang sejalan dengan progresivisme pendidikan ini) bersifat take and give (saling menerima dan memberi) antara pendidik dan peserta didik.

\footnotetext{
${ }^{40}$ Lihat http://www.deliveri.org/guidelines/how/hm14 1i.htm.
} 
Dengan kata lain, pendidik bisa memberi dan/atau menerima ilmu dari peserta didik; begitu sebaliknya, peserta didik bisa memberi dan/atau menerima ilmu dari pendidik. Proses pembelajarannya bersifat dialogis dan demokratis; bukan monologis dan otoriter.

\section{F. Progresivisme John Dewey dan Pendidikan Partisipatif Perspektif Pendidikan Islam}

Progresivisme pendidikan Dewey yang mengandung asas pendidikan partisipatif menyatakan bahwa kurikulum pendidikan harus berisi pengalaman-pengalaman peserta didik yang mana pengalaman tersebut diiskusikan di dalam ruang sekolah, dan jika terdapat permasalahan sosial yang dialami oleh peserta didik, maka harus didiskusikan bersama upaya pemecahannya. Dengan demikian kurikulum progresivisme pendidikan Dewey berupa kurikulum berbasis pengalaman hidup. Dalam hal ini, kurikulum pendidikan progresivisme sejalan dengan kurikulum pendidikan Islam. Dalam Islam, muatan kurikulum pendidikannya juga berisi tentang persoalan-persoalan kemanusiaan yang didiskusikan untuk dicari pemecahannya melalui ruang pendidikan, baik formal, non formal atau informal.

Dalam kurikulum pendidikan progresivisme, materi pelajaran juga berupa teori-teori yang relevan dengan kebutuhan peserta didik. Dalam pendidikan Islam, kurikulum pendidikannya juga berisi tentang teori-teori yang dikemukakan oleh ulama atau ilmuwan Muslim sebelumnya, bahkan teori-teori ilmuwan non-Muslim yang tidak bertentangan dengan nilai-nilai Islam terkadang dipakai dalam pendidikan Islam. Dengan demikian, sampai di sini, antara kurikulum pendidikan progresivisme dengan kurikulum pendidikan Islam tidak ditemukan suatu perbedaan yang signifikan.

Selain itu, progresivisme pendidikan amat menekankan materi kurikulum pendidikan yang bersifat praktis-pragmatis. Hal ini sejalan dengan asas kemanfaatan dalam pendidikan Islam. Islam menekankan adanya nilai guna atau asas kemanfaatan dalam kurikulum pendidikannya. Dalam artian, materi pelajaran yang diberikan kepada peserta didik harus berupa materi-materi yang bersifat praktis dan tidak hanya teoritis, agar bisa dimanfaatkan oleh peserta didik dalam praktik 
kehidupannya. Dengan begitu, kurikulum pendidikan yang bersifat praktis-pragmatis diikuti dalam progresivisme pendidikan Dewey dan pendidikan Islam. Asas kemanfaatan dalam pendidikan Islam memberi bekal yang berguna bagi kepentingan peserta didik di dunia dan akhirat. Bedanya, progresivisme pendidikan (Dewey) hanya menekankan pada aspek tujuan duniawi, sementara pendidikan Islam menekankan aspek keduanya; dunia dan akhirat.

Lebih lanjut, progresivisme pendidikan Dewey menekankan perlunya materi kurikulum pendidikan yang tidak terlalu padat, karena bisa membuat peserta didik stress dan tidak enjoy dalam proses belajarnya. Kurikulum pendidikan perlu diusahakan seminimal mungkin tetapi mendalam dalam proses pembelajarannya. Kalau suatu materi kurikulum sudah dikuasai oleh peserta didik, maka perlu ditambahkan materi kurikulum yang lain. Ini juga tidak bertentangan dengan konsep kurikulum pendidikan Islam. Menurut al-Ghazali, dalam mempelajari suatu ilmu, jangan berpindah dulu ke ilmu lain, sebelum ilmu yang dipelajari dikuasai.

Di samping itu, progresivisme pendidikan menekankan adanya kurikulum pendidikan yang sesuai dengan kebutuhan kerja. Dewey menyatakan bahwa pendidikan adalah kerja, jadi kurikulumnya harus berbasis kebutuhan kerja. Hal ini agak tidak sejalan dengan konsep pendidikan Islam. Dalam pendidikan Islam, kurikulum pendidikannya tidak selalu dirancang untuk memenuhi kebutuhan kerja, sehingga tidak mesti memberikan materi kurikulum yang berbasis pada kebutuhan kerja. Meski demikian, bukan berarti pendidikan Islam menolak muatan kurikulum pendidikan yang berorientasi pada kerja. Akan tetapi, orientasi tersebut bukan menjadi tujuan utama. Kurikulum pendidikan Islam lebih berorientasi pada kebutuhan penataan moral peserta didik. Pemenuhan kebutuhan kerja hanya sebagai orientasi kedua setelah pemenuhan kebutuhan moral.

Pendidikan partisipatif dalam Progresivisme pendidikan Dewey sangat menekankan adanya proses pendidikan yang demokratis, terbuka dan anti otoriter. Pendidikan yang demokratis sejalan dengan pendidikan pembebasan dalam pendidikan Islam yang membutuhkan ruang dialogis dan komunikatif serta terbuka dalam proses pembelajarannya. Dalam hal 
ini M. Athiyah al-Abrasy ${ }^{41}$ dengan konsep al-Tarbiyah al-Istiqlaliyah (pendidikan pembebasan) menyatakan;

"Bahwa asas terpenting al-Tarbiyah al-Istiqlaliyah adalah membiasakan peserta didik berpegang teguh pada kemampuan diri sendiri sebagai refleksi dasar dari sikap percaya diri, percaya dengan pikiran sendiri. Azas ini hanya dipakai jika proses pendidikan dilakukan dengan terbuka dan dialogis."

Meskipun demikian, jika dicermati lebih mendalam, akan tampak perbedaan yang sangat esensial antara teori progresifis dengan teori yang didasarkan pada kajian pendidikan Islam. Mengingat, dalam pendidikan Islam ada sesuatu yang tidak pernah disinggung oleh teori progresifis, yaitu nilai-nilai ilahiah.

Nilai-nilai partisipatif dalam Progresivisme pendidikan Dewey tidak mengarahkan untuk mengenal diri sendiri. Pendidikan yang dikembangkan Dewey juga tidak mengarahkan pengetahuan peserta didik kepada pencipta manusia atau Tuhan. Padahal mengenal Tuhan sebenarnya adalah kebutuhan mendasar manusia, sehingga perlu dilakukan lebih lanjut guna memagari kesucian fitrah manusia. Dewey juga tampak menolak adanya hereditas, yakni menyangkal keabsolutan eksistensi dari pembawaan, karena menurutnya, hereditas itu bagian dari lingkungan. Hereditas dibentuk berdasar pengalaman bukan bawaan sejak lahir. $^{42}$

Dewey juga menegaskan proses pendidikan yang berlaku seumur hidup (live long education). Hal ini sejalan dengan konsep pendidikan Islam. Muhaimin ${ }^{43}$ menegaskan sebuah prinsip yang menjadi dasar bagi proses pendidikan Islam, yaitu prinsip pendidikan seumur hidup. Prinsip ini berpandangan bahwa setiap manusia diharapkan untuk selalu berkembang sepanjang hidupnya, yang menegaskan bahwa masa sekolah bukan satu-satunya masa bagi seseorang untuk belajar, melainkan hanya sebagian dari waktu belajar yang akan berlangsung seumur hidup. Kata

${ }^{41}$ M. Athiyah al-Abrasy, Ruh al-Islam (Mesir: Mathba'ah Lajnah al-Bayan al'Arabi, 1964), 285.

${ }^{42}$ Muis Sad Iman, Pendidikan Partisipatif, 116-117.

${ }^{43}$ Muhaimin, Konsep Pendidikan Islam (Solo: Ramadlan, 1993), 38. 
Nabi: Tuntutlah ilmu dari buaian sampai ke liang lahad. Setiap saat umat Islam dianjurkan memohon kepada Allah agar senantiasa bertambah ilmu pengetahuannya. ${ }^{44}$.

Dengan memahami kajian di atas maka dapat ditegaskan bahwa belajar tanpa batas bukan sekadar belajar sepanjang hayat, dan juga bukan sekadar belajar untuk hidup, melainkan lebih dari itu. Menurut Noeng Muhadjir, belajar tanpa batas setidak-tidaknya mengandung tiga makna, yaitu pengembangan optimal kemampuan manusia, pengembangan optimal kreasi wahana kehidupan manusia dan pengembangan optimal kesejahteraan manusiawinya manusia sebagai makhluk sosial dan makhluk ciptaan Allah. ${ }^{45}$ Dalam kaitan ini konsep pendidikan seumur hidup Dewey sejalan dengan konsep pendidikan Islam. Dewey menyatakan bahwa hidp itu merupakan pendidikan atau pendidikan merupakan kehidupan itu sendiri. Bedanya, konsep pendidikan Dewey memang tidak mengarahkan peserta didik untuk lebih mendekatkan diri kepada Tuhannya.

Tujuan pendidikan progresivisme Dewey yang bermuatan nilainilai parisipatif lebih menekankan pada tujuan pendidikan yang bersifat pragmatis di dunia. Dalam artian, pendidikan harus bisa membekali peserta didik berbagai materi yang bisa difungsikan untuk bekerja dalam hidup. Orientasi pendidikan yang dikenalkan Dewey dalam konsep progresivismenya bersifat duniawi an-sich, dan sama sekali tidak menyinggung perlunya pembekalan kepada peserta didik akan materimateri yang dibutuhkan untuk kehidupan setelah mati (eskatologis). Bisa jadi, hal ini karena rapuhnya keyakinan Dewey akan adanya dunia metafisika. Sehingga konsep pendidikannya sama sekali tidak berdimensi ilahiyah. Dalam hal ini tujuan pendidikan Dewey jelas tidak sejalan dengan pendidikan Islam.

Tujuan pendidikan Islam sangat kental bernuansa religius dan penuh dengan dimensi ilahiyah. Meski demikian, pendidikan Islam tidak menolak pentingnya pemberian bekal bagi peserta didik akan hal-hal yang berguna dalam kehidupan di dunia. Pendidikan Islam juga sangat

${ }^{44}$ QS. 20: 114.

${ }^{45}$ M. Jindar Wahyudi, Nalar Pendidikan Qur'ani (Yogyakarta: Apeiron Philotes, 2006), 66. 
menekankan pengtingnya pembekalan hidup di dunia melalui dunia pendidikan, karena memang kehidupan di dunia merupakan ladang untuk mencapai kehidupan yang baik di akhirat.

\section{G. Kesimpulan}

Konsep pendidikan partisipatif dalam progresivisme pendidikan John Dewey merupakan konsep pendidikan yang mengacu pada teoriteori John Dewey yang berpijak pada asas-asas progresivitas. Asas progresivitas berprinsip pada sikap optimistis dalam memandang kemajuan peserta didik dalam proses pendidikannya. Progresivisme pendidikan Dewey menjadikan pengalaman hidup manusia sebagai pijakan dalam melakukan perubahan-perubahan ke depan melalui proses pendidikan.

Konsep progresivisme pendidikan John Dewey yang megandung asas pendidikan partisipatif dalam pandangan pendidikan Islam bisa dipertegas: bahwa terdapat beberapa aspek kesesuaian (terutama dalam hal kemanfaatan yang bersifat duniawi), dan terdapat banyak aspek perbedaan yang sangat prinsip (terutama mengenai hal-hal yang bersifat metafisik-spiritual). Dengan demikian, ketika akan menerapkan asas partisipatif dalam konsep pendidikan Dewey di dalam kehidupan umat Islam, perlu difilter terlebih dahulu dengan kacamata nilai-nilai Islam. Apabila tidak bertentangan dengan nilai-nilai Islam, maka perlu diterapkan; namun apabila bertentangan dengan nilai-nilai Islam, maka tidak perlu diterapkan (cukup dijadikan pengetahuan saja).

\section{DAFTAR PUSTAKA}

Ag. Soejono, Aliran Baru dalam Pendidikan, bagian 1 (Bandung: CV. Ilmu, 1978).

Djalaludin \& Abdullah Idi, Filsafat Pendidikan (Jakarta: Gaya Media Pratama, 1997)

Endang Daruni Asdi \& A. Husnan Aksara, Filsif-Filsuf Dunia dalam Gambar (Yogyakarta: Karya Kencana, 1982).

Hamdani Ali, Filsafat Pendidikan (Yogyakarta: Kota Kembang, 1993).

http://www.deliveri.org/guidelines/how/hm14_1i.htm 
Imam Barnadib, Filsafat Pendidikan: Sistem \& Metode, cet. 9 (Yogyakarta: ANDI, 1997).

Imam Barnadib, Filsafat Pendidikan (Yogyakarta: Adicita Karya Nusa, 2002)

I. Djumhur \& H. Danasuparta, Sejarah Pendidikan (Bandung: CV. Ilmu, 1974).

John Dewey, Democracy and Education, an Introduction to the Philosophy

of Education, Twenty-Third Printing (USA: The Macmillan Company, 1950).

John Dewey, Freedom and Culture (Capricorn books edition, 1963).

Joe Park, Selected Reading in the Philosophy of Education (New York: The MacMillan Company, 1958).

J. Donald Butler, Four Philosophies and Their Practice in Education and Religion (New York: Harper and Brothers, 1951).

Muis Sad Iman, Pendidikan Partisipatif (Yogyakarta: Safiria Insania Press $\&$ MSI UII, 2004).

Murtadha Muthahari, Fitrah (Jakarta, 1419/1998)

Theodore Brameld, Philosophies of Education in Cultural Perspective (New York: The Dryden Press, 1958).

Wasty Soemanto \& Hendyat Soetopo, Dasar \& Teori Pendidikan Dunia:

Tantangan bagi para Pemimpin Pendidikan (Surabaya: Usaha Nasional, 1982).

Y.B. Suparlan, Aliran-Aliran Baru dalam Pendidikan (Yogyakarta: Andi Offset, 1984). 